\title{
Molecular Characterization of Desmoid Tumors: Decryption of the Enigma
}

\author{
Trenton L. Place James J. Mezhir \\ Department of Surgery, Division of Surgical Oncology, University of lowa Hospitals and Clinics, lowa City, IA, USA
}

Desmoid tumors have long been known as an 'enigma' due to their unusual biology and aggressive clinical behavior [1-3]. These tumors may arise from the extremities, abdominal wall, intestinal wall and mesentery, head and neck, and breast and can be sporadic or associated with familial adenomatous polyposis [4-9]. Despite being histologically benign tumors, desmoids are locally aggressive and can cause debilitating symptoms and death [10]. It has been reported that aggressive measures to surgically extirpate desmoid tumors can result in significant morbidity and mortality, which has resulted in changes in management of these lesions [4]. Alternatives such as observation, radiation, and chemo/hormonal therapy have been explored, but with unproven durable success [11, 12]. Molecular and genetic characterization of desmoid tumors must be done in order to ultimately develop novel, effective targets for therapy.

Several studies have been performed to begin to 'decrypt' these enigmatic tumors in an effort to better understand the etiology and genetic machinery behind this disease. A sample of studies is shown in table 1. Many of the studies to date have found signaling changes in the $\beta$-catenin pathway, and in addition, chromosomal alterations. From these studies, it is reasonable to conclude that desmoid tumors are highly heterogeneous and require further investigation.

In this issue of ONKOLOGIE, Erben and colleagues comprehensively evaluate 9 patients with desmoid tumors of the abdomen $(n=7)$ and extremity $(n=2) ; 8 / 9$ were sporadic desmoids while 1 patient had familial adenomatous polyposis [13]. Resection only was the treatment for 4 patients while 5 patients had radiation therapy, 1 patient chemotherapy, and 2 patients hormonal therapy. 3 patients recurred during the follow-up period. Despite this being a small sample size, it is a snapshot representation of patients with desmoid tumors who are often treated with multimodality therapy.

The authors aimed to expand the existing knowledge of the chromosomal abnormalities associated with desmoid tumors by utilizing single-nucleotide polymorphism array (SNP-A) karyotyping. This technology allows for the high resolution characterization of chromosomal abnormalities down to the kilobase level, whereas previous studies on desmoid tumors have largely employed techniques suited for the detection of megabase or larger chromosomal alterations [14]. In conjunction with SNP-A, the authors performed traditional DNA sequencing on a number of genes known to be mutated in desmoid tumors, including $\beta$-catenin (CTNNB1) and $A P C$.

Using these combined methodologies, the authors validated existing data on the presence of mutations in CTNNB1, and losses in chromosome 8q, which contains the APC locus. In addition, they detected numerous other small deletions and insertions that have previously not been reported in desmoid tumors. The most significant of these novel lesions was a heterozygous, somatic deletion affecting a small region of chromosome $8 \mathrm{p} 23$, which was observed in $44 \%$ of the tumors tested. This deletion falls within the CUB and Sushi multiple domains1 (CSMD1) gene, a putative tumor suppressor that is also mutated or deleted in tumors of the head and neck, colon, breast, and prostate $[15,16]$. Furthermore, the authors noted a correlation between CSMD1 deletion and relapse, as 3 of the 9 patients with disease recurrence at the time of publication had exhibited a CSMD1 deletion. The small sample size and short follow-up time limit the authors' ability to make firm conclusions regarding the prognostic significance of these otherwise exceptional and novel data.

The management of desmoid tumors remains a challenge to the patient and the clinician. However, studies such as this by Erben and colleagues add to the arsenal of data that will eventually lead to novel therapies for this disease. As for all patients presenting with complex malignancies such as desmoid tumors, continued efforts for tissue collection and multi-institution and protocol-based regimens are justified.

\section{Disclosure Statement}

The authors have no conflict of interest.

\section{KARGER \\ Fax +497614520714 \\ Information@Karger.de}

www.karger.com (c) 2012 S. Karger GmbH, Freiburg

0378-584X/12/3511-0641\$38.00/0

Accessible online at:

www.karger.com/onk
James J. Mezhir, MD

Division of Surgical Oncology and Endocrine Surgery

University of Iowa Hospitals and Clinics

200 Hawkins Drive; 4642 JCP

Iowa City, IA 52242, USA

james-mezhir@uiowa.edu 
Table 1. Select recent studies evaluating the biology of desmoid tumors

\begin{tabular}{|c|c|c|c|c|c|c|}
\hline $\begin{array}{l}\text { Author, year } \\
\text { [ref.] }\end{array}$ & $\mathrm{n}$ & Sites included & $\begin{array}{l}\text { Analysis } \\
\text { technique }\end{array}$ & Controls & Pertinent findings & Conclusions \\
\hline $\begin{array}{l}\text { Mignemi et al., } \\
2012 \text { [17] }\end{array}$ & 27 & extremity & IHC of TMA & $\begin{array}{l}\text { scar, normal } \\
\text { fibrous tissue }\end{array}$ & $\begin{array}{l}\text { increases in p-B-catenin, } \\
\text { SMAD2/3, COX2 } \\
\text { Estrogen receptor B } \\
\text { present in all specimens }\end{array}$ & $\begin{array}{l}\text { TGFB signaling is activated in } \\
\text { desmoid tumors } \\
\text { COX } 2 \text { may be a novel target } \\
\text { for therapy along with androgen } \\
\text { therapy }\end{array}$ \\
\hline $\begin{array}{l}\text { Huss et al., } 2012 \\
{[18]}\end{array}$ & 56 & $\begin{array}{l}\text { mesenteric, } \\
\text { abdominal wall, } \\
\text { extremity }\end{array}$ & $\begin{array}{l}\text { IHC, mutational } \\
\text { analysis }\end{array}$ & fibrosis & $\begin{array}{l}\text { mesenteric tumors more } \\
\text { often had mutations in } \\
\text { B-catenin gene than } \\
\text { non-mesenteric tumors }\end{array}$ & $\begin{array}{l}\text { mesenteric desmoids may have } \\
\text { genetic differences compared } \\
\text { to non-mesenteric tumors }\end{array}$ \\
\hline $\begin{array}{l}\text { Cho et al., } 2012 \\
\text { [19] }\end{array}$ & 6 & $\begin{array}{l}\text { abdominal, } \\
\text { extremity }\end{array}$ & IHC, WB & $\begin{array}{l}\text { matched } \\
\text { normal tissue }\end{array}$ & $\begin{array}{l}\text { Increased B-catenin } \\
\text { expression in tumors } \\
\text { Variable expression } \\
\text { of c-SRC and c-Kit }\end{array}$ & $\begin{array}{l}\text { variable response to different } \\
\text { targeted agents in desmoid } \\
\text { tumors } \\
\text { is likely due to the heterogeneity } \\
\text { of the disease }\end{array}$ \\
\hline $\begin{array}{l}\text { Salas et al., } 2010 \\
\text { [20] }\end{array}$ & 194 & $\begin{array}{l}\text { abdominal, } \\
\text { abdominal wall, } \\
\text { extremity }\end{array}$ & $\begin{array}{l}\text { comparative } \\
\text { genomic } \\
\text { hybridization }\end{array}$ & $\begin{array}{l}\text { sex-matched } \\
\text { DNA }\end{array}$ & $\begin{array}{l}76 \% \text { of tumors had } \\
\text { no genomic changes } \\
\text { loss of } 6 \mathrm{q} \text { and } 5 \mathrm{q} \text {, gain } \\
\text { of } 20 \mathrm{q} \text { and } \mathrm{Chr} 8 \text { in } 40 / 46 \\
\text { tumors with alterations }\end{array}$ & $\begin{array}{l}\text { mutations in } A P C \text { and } \\
C T N N B 1 \text { did not account for } \\
\text { tumorogenicity in all cases } \\
\text { further study of the novel } \\
\text { genetic alterations is warranted }\end{array}$ \\
\hline $\begin{array}{l}\text { Domont et al., } \\
2010 \text { [21] }\end{array}$ & 155 & $\begin{array}{l}\text { abdominal, } \\
\text { extremity, trunk, } \\
\text { head/neck }\end{array}$ & $\begin{array}{l}\text { B-catenin gene se- } \\
\text { quencing }\end{array}$ & NA & $\begin{array}{l}\text { B-catenin mutations were } \\
\text { present in } 83 \% \text { of cases } \\
\text { DFS was worse in B-catenin } \\
\text { mutated tumors }\end{array}$ & $\begin{array}{l}\text { B-catenin mutations are } \\
\text { present in the majority of } \\
\text { extra-abdominal desmoid } \\
\text { tumors and is a potential } \\
\text { prognostic marker }\end{array}$ \\
\hline
\end{tabular}

IHC, immunohistochemistry; TMA, tissue microarray; WB, western blot; NA, not available; DFS, disease free survival.

\section{References}

1 Lewis JJ, Boland PJ, Leung DH, et al.: The enigma of desmoid tumors. Ann Surg 1999;229:866-72.

2 Posner MC, Shiu MH, Newsome JL, et al.: The desmoid tumor. Not a benign disease. Arch Surg 1989;124:191-6.

3 Okuno S: The enigma of desmoid tumors. Curr Treat Options Oncol 2006; 7:438-43.

$\checkmark 4$ Smith AJ, Lewis JJ, Merchant NB, et al.: Surgical management of intra-abdominal desmoid tumours. Br J Surg 2000;87:608-13.

$\checkmark 5$ Hoos A, Lewis JJ, Urist MJ, et al.: Desmoid tumors of the head and neck--a clinical study of a rare entity. Head Neck 2000;22:814-21.

6 Neuman HB, Brogi E, Ebrahim A, et al.: Desmoid tumors (fibromatoses) of the breast: a 25 -year experience. Ann Surg Oncol 2008;15:274-80.

7 Stojadinovic A, Hoos A, Karpoff HM, et al.: Soft tissue tumors of the abdominal wall: analysis of disease patterns and treatment. Arch Surg 2001; 136:70-9.

$\checkmark 8$ Merchant NB, Lewis JJ, Woodruff JM, et al. Extremity and trunk desmoid tumors: a multifactorial analysis of outcome. Cancer 1999;86:2045-52.

$\checkmark 9$ Church J, Berk T, Boman BM, et al.: Staging intra-abdominal desmoid tumors in familial adenomatous polyposis: a search for a uniform approach to a troubling disease. Dis Colon Rectum 2005; 48:1528-34.
10 Quintini C, Ward G, Shatnawei A, et al.: Mortality of intra-abdominal desmoid tumors in patients with familial adenomatous polyposis: a single center review of 154 patients. Ann Surg 2012;255:511-6.

11 de Camargo VP, Keohan ML, D'Adamo DR, et al.: Clinical outcomes of systemic therapy for patients with deep fibromatosis (desmoid tumor). Cancer 2010;116:2258-65.

12 Gounder MM, Lefkowitz RA, Keohan ML, et al.: Activity of sorafenib against desmoid tumor/deep fibromatosis. Clin Cancer Res 2011;17:4082-90.

13 Erben P, Nowak D, Sauer C, et al.: Molecular analysis of desmoid tumors with a high-density single-nucleotide polymorphism array identifies new molecular candidate lesions. Onkologie 2012; 35: DOI: $10.1159 / 000343744$

14 Sato-Otsubo A, Sanada M, Ogawa S: Singlenucleotide polymorphism array karyotyping in clinical practice: where, when, and how? Semin Oncol 2012;39:13-25.

15 Sun PC, Uppaluri R, Schmidt AP, et al.: Transcript map of the 8 p23 putative tumor suppressor region. Genomics 2001;75:17-25.

16 Ma C, Quesnelle KM, Sparano A, et al.: Characterization CSMD1 in a large set of primary lung, head and neck, breast and skin cancer tissues. Cancer Biol Ther 2009;8:907-16.
17 Mignemi NA, Itani DM, Fasig JH, et al.: Signal transduction pathway analysis in desmoid-type fibromatosis: TGFbeta, COX2 and sex steroid receptors. Cancer Sci 2012; doi: 10.1111/cas.12037.

18 Huss S, Nehles J, Binot E, et al.: beta-Catenin (CTNNB1) mutations and clinicopathological features of mesenteric desmoid-type fibromatosis. Histopathology 2012; doi: 10.1111/j.1365-2559.2012.04355.x.

19 Cho NL, Carothers AM, Rizvi H, Hasson RM, Redston M, Bertagnolli MM: Immunohistochemical and molecular analysis of tyrosine kinase activity in desmoid tumors. J Surg Res 2012; 173:320-6.

20 Salas S, Chibon F, Noguchi T, et al.: Molecular characterization by array comparative genomic hybridization and DNA sequencing of 194 desmoid tumors. Genes Chromosomes Cancer 2010;49: 560-8.

21 Domont J, Salas S, Lacroix L, et al.: High frequency of beta-catenin heterozygous mutations in extra-abdominal fibromatosis: a potential molecular tool for disease management. Br J Cancer 2010;102:1032-6. 